\title{
ナップ振動における背後空気室の効果に関する研究 Effect of Confined Air behind the Nappe on Nappe Oscillation
}

\author{
名合宏之* ・前野詩朗 $* *$ ・石井宏幸 $* * *$
}

By Hiroshi NAGO, Shiro MAENO and Hiroyuki ISHII

To clarify the basic characteristics of nappe oscillation, the effect of confined air behind the nappe was investigated experimentally. As a result, it is clarified that the shift of oscillation mode is caused by nappeconfined air interaction near the natural frequency of confined air. That is, the confined air behind the nappe plays an important role to maintain and amplify the nappe oscillation. If the natural frequency of nappe approaches to the natural frequency of confined air from the lower level, the mode of the nappe oscillation shifts to the higher mode and the nappe begins to oscillate like a resonance box with the natural frequency of confined air.

Keywords : nappe oscillation, oscillation mode, confined air, gate vibration

\section{1. まえがき}

越流型の堰や砂防ダムにおいて、ナップ（越流水脈）がある水理条件、気象条件、構造条件のもとで激し く振動することがあり、それにともなって発生するゲート振動や騒音は、構造物の安全性のみならず周辺地 域に対する環境面から問題となっている。したがって、その振動機構を解明し、ナップ振動を防止すること は工学的に重要な課題である。振動の発生にはナップ背後に閉じこめられた空気室の圧力とナップ外の空気 圧との差が重要な影響要因となっているとの観点から、従来より、振動防止法としては、越流水脈を分割す るスポイラーを取り付けることによって内外気圧差を減少させる方法が実用的な方法として採用されている。 しかし、このような振動防止対策も振動発生のメカニズムを考虑した統一的な基準に基つくるのではなく、 試行錯誤的に求められてきた経験的事例に基づいて決められているのが現状である。

このような実状を背景として、著者らは、従来より、フラップゲートを越流するナップの振動特性を弾性 相似模型ゲートおよび固定ゲートを用いて実験的に検討してきた 1,2,3,4)。その結果、振動していないナッ プに風をあてることにより写真ー 1 に見られるようにナップが激しく振動し、その振動周波数は Schwartz ${ }^{5)}$

\footnotetext{
* 正会員 工博 岡山大学教授 工学部土木工学科

（干700 岡山市津島中 $3-1-1$ ）

** 正会員 工博 岡山大学助手 工学部土木工学科

$* * *$ 正会員 工修 建設省土木研究所

（テ305 茨城県つくば市大字旭 1 番地）
} 
が提案した予測式とょく一致することや、風に よって励起されるゲート振動は、ナップの振動に 起因する強制振動であること、さらに、ナップの 振動防止に対するスポイラーの効果を実験的に明 らかにしている。また、竹林ら6)は現地計測をも 含む広範な実験を行い、空気とナップの相対速度 による不安定性によりナップ振動が発生し、ナッ プ背後の空気室との連成によりナップ振動が安定 することなどを明らかにしている。これらの研究 により、ナップ振動の基本的な特性はある程度明 らかになってきているが、ナップ振動の周波数の 決定要因や振動が増大するときの振動モードの遷
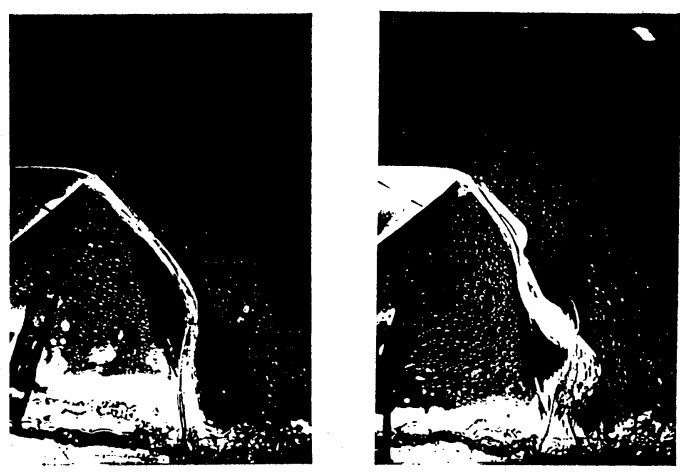

写真- 1 風によるナップの振動 移現象などについては明らかにされていない。とくに、ナップ振動に重要な役割を果たすと考えられる背後 空気室の効果については、竹林ら6)がスリットからの鉛直落下水脈を対象として実験的に検討しているが、 堰を越流する場合のナップの背後空気室の効果については、これまで検討されていない。以上のことを考虑 して、本研究は、ナップ背後の空気室の大きさを独立して変化させることのできる実験装置を用いて、越流 ナップの振動特性に与える背後空気室の効果について実験的に検討しようとするものである。

\section{2. 実験方法}

実験には、図ー 1 に示すような鉊直固定刃型堰を用いた。堰の幅は $64.3 \mathrm{~cm}$ である。空気室の壁は厚さ $2.0 \mathrm{~cm}$ の合板製であるが、堰より下流側の壁の一面は振動状態を観察できるように、厚さ $2.0 \mathrm{~cm}$ のアクリル 板を用いた。ナップ背後の空気室の壁は、堰の 真下から奥へ $80 \mathrm{~cm}$ の所までの位置に固定可能 であり、これにより空気室体積を変えることが できる。また、床板の固定位置を変えることに より落下高を調節できる。ナップの振動特性を 調へろために、流量、落下高、ナップ背後の空 気室の体積を変化させて実験を行った。実験条 件は表ー 1 に示している。ナップの振動数の測 定は、ストロボスコープを用いて行い、その閃 光周波数をナップの振動に同調させて、ナップ 形状が静止して見える状態のストロボスコープ の閃光周波数をナップの振動周波数とした。な お、本実験においては送風は行っていない。

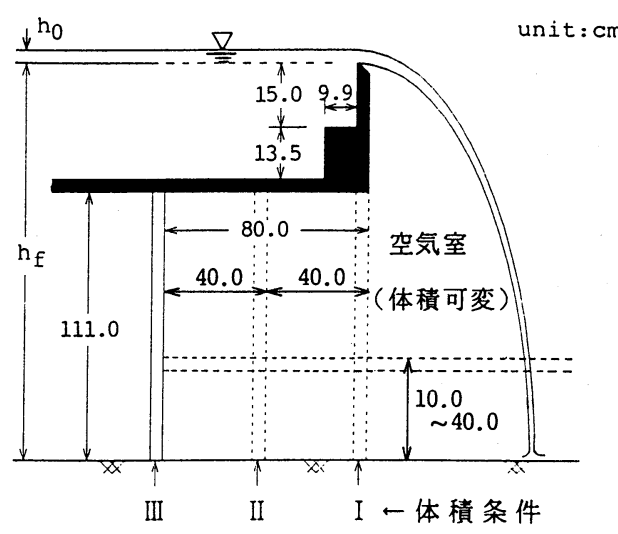

図 -1 実験装置の概要

\section{表- 1 実験条件}

\begin{tabular}{|c|c|}
\hline 流 量 Q & 越流水深 $\mathrm{h}_{0 \text { を }} 1.7 \mathrm{~cm} \sim 3.2 \mathrm{~cm}$ まで $0.3 \mathrm{~cm}$ 刻みで変化させる。 $(\mathrm{Q}=3.1 \sim 7.8 \mathrm{l} / \mathrm{s})$ \\
\hline 落下高 $h_{f}$ & $115 \sim 155 \mathrm{~cm}$ まで $10 \mathrm{~cm}$ 刻みで変化させる。 \\
\hline $\begin{array}{l}\text { ナップ背後 } \\
\text { 空気室体積 }\end{array}$ & 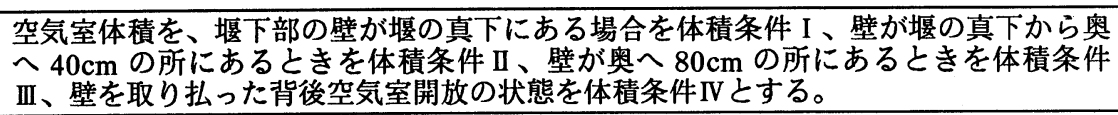 \\
\hline
\end{tabular}




\section{3. 実験結果および考察}

写真ー 2 はナップの振動している様子を撮影したものである。写真より、 ナップは総落下高の半分程度落下した後、振動の波がナップに顕著に現れ て、その数は一つではなく数個存在することがわかる。以下においては実 験結果をもとに、ナップ振動に与える背後空気室体積の影響を検討する。

3.1 ナップ背後空気室の固有振動数の特性

ナップの振動には背後の空気室の圧力変動が関係しているのではないか ということが従来より指摘されている。そこで、ここではまず、本実験で 対象とする条件下で、空気室の固有振動数がどのように変化するかを検討 する。空気室の固有振動数の計算には、ナップと空気室との連成系として 導かれる次式7)を用いた。

$$
f=\frac{1}{2 \pi} \sqrt{\frac{P_{0} S_{w}}{\rho_{w} \bar{h} V}}
$$

ここに、 $P_{0}$ : 大気圧, $S_{w}$ :ナップの面積, $\rho_{w}$ : 水の密度, $\bar{h}:$ ナップの厚さの平均值, $V:$ 空気 室体積である。上式にもとづくナップ背後空 気室の振動数の特性は以下のようである。

図ー 2 は落下高一定で空気室の大きさを 変化させる場合の空気室固有振動数を流量 をパラメーターとして示している。また、 図ー 3 は、流量一定で空気室の大きさを変 化させる場合について、落下高をパラメー ターとして示している。両図より、空気室 固有振動数は、空気室の大きさが大きくな るほど小さくなり、空気室体積が小さい場 合には、わずかの体積変化で振動数が大き く変化することがわかる。落下高一定で流 量を大きくすると、ナップの平均厚さが大 きくなるとともに空気室体積も若干大きく なり、空気室固有振動数は小さくなる。そ の傾向はいずれの体積条件においても同様 である。流量一定で落下高が変化すると、 体積条件 Пおよび II の場合には、落下高が 変化して空気室体積が大きく変化しても空 気室固有振動数はほとんど変化しないこと がわかる。体積条件 I の場合には、体積条 件 II および III の場合に比へて落下高の変化 による体積変化は小さいが、落下高が大き くなると空気室固有振動数は小さくなるこ とがわかる。

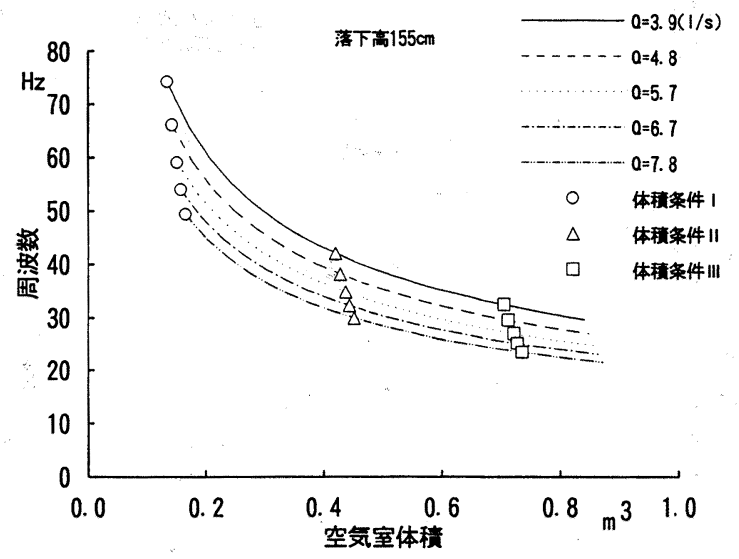

図-2 空気室固有振動数（落下高一定）

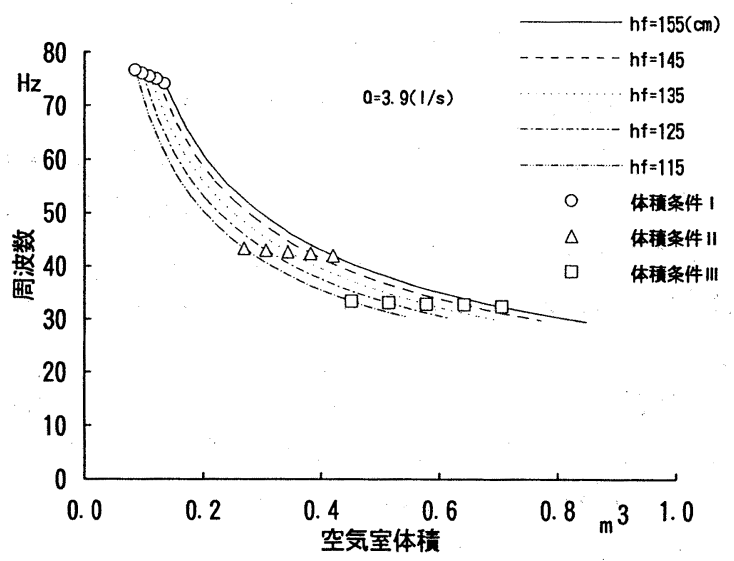

図-3 空気室固有振動数（流量一定） 


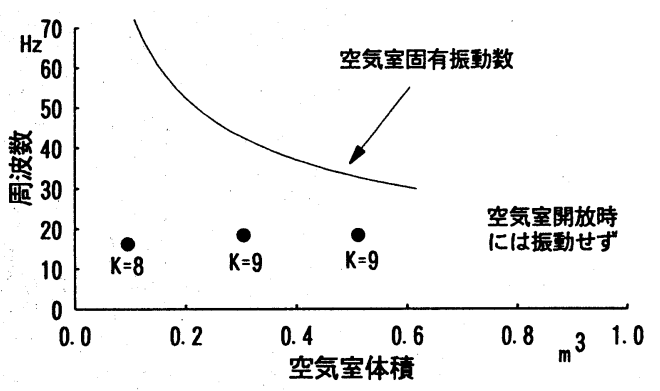

(a) $Q=3.9 \ell / s$

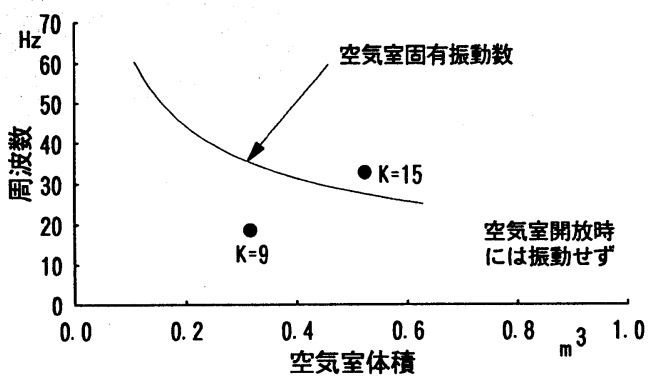

(b) $Q=5.7 \ell / \mathrm{s}$

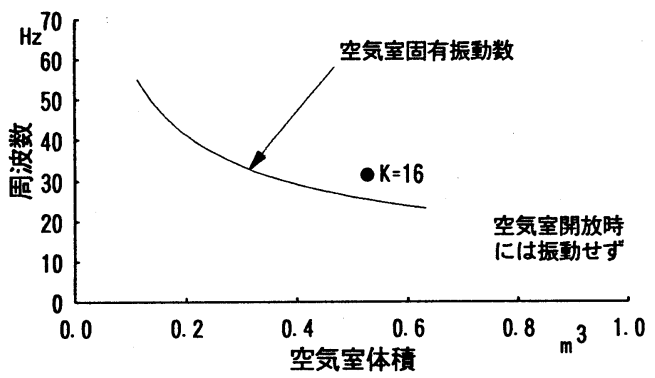

(c) $Q=6.7 \ell / \mathrm{s}$

図-4 空気室固有振動数と実験値との比較 （落下高 $125 \mathrm{~cm}$ ）

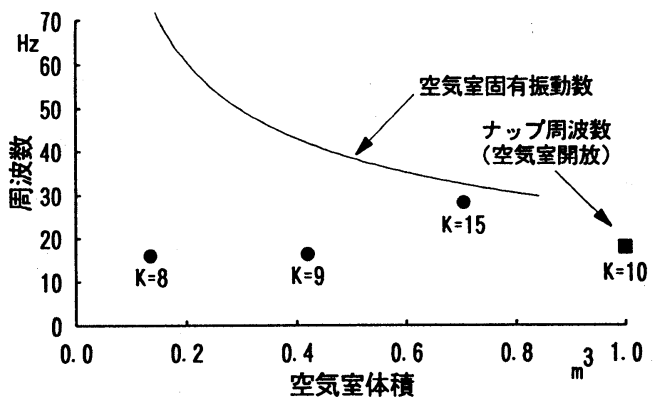

(a) $Q=3.9 \ell / s$

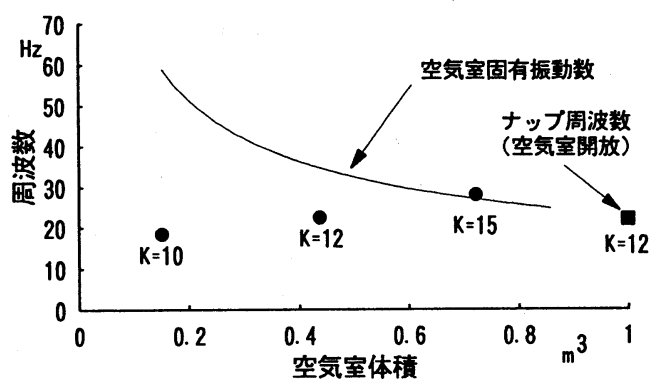

(b) $Q=5.7 \ell / \mathrm{s}$

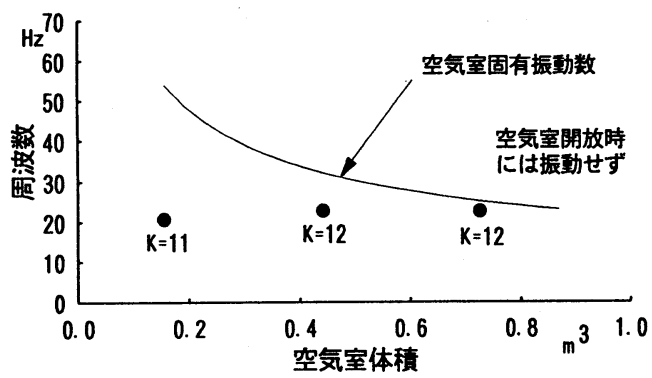

(c) $Q=6.7 \ell / \mathrm{s}$

図-5 空気室固有振動数と実験值との比較

（落下高 $155 \mathrm{~cm}$ ）

\section{2 背後空気室体積のナップ周波数に与える影響}

図ー 4 および図ー 5 は落下高 $125 \mathrm{~cm}$ および $155 \mathrm{~cm}$ の場合の背後空気室体積と周波数との関係をいくつか の流量条件について示したものである。図中ののの記号は体積条件 I 〜 III実験值を示し、日の記号は空気 室開放時にナップが振動した場合の実験值である。また、K は Schwartzの $(\mathrm{K}+1 / 4)$ 則の K の値（ナップが 振動している状態でナップ上に存在する波の数の整数部分）を示している。これらの図より以下のことがわ かる。

ナップ背後の空気室体積が大きくなり、背後空気室の固有振動数がナップの振動数に近づくと、落下高 $125 \mathrm{~cm}$ で流量 $3.91 / \mathrm{s}$ および落下高 $155 \mathrm{~cm}$ で流量 $6.71 / \mathrm{s}$ の場合を除いて、 $\mathrm{K}$ の值が大きくなり、ナップ上に存 在する波の数が多くなる。すなわち、ナップの振動モードが高いモードに遷移し、空気室の固有振動付近 で振動することがわかる。ナップの周波数が高いモードに遷移したときには、ナップの振動はかなり激し くなった。また、空気室開放の状態においては、落下高 $155 \mathrm{~cm}$ で流量が $3.91 / \mathrm{s}$ および $5.71 / \mathrm{s}$ の場合のみ、 ナップの振動が発生していることがわかる。このときの振動数は、空気室体積が小さい場合（体積条件 I お 
よび II ）のナップの振動数に近いことがわかる。空気室 開放時には空気室の圧力変動がナップに与える影響がな くなることを考虑すると、背後空気室と無関係なナップ そのものが有する固有振動が存在することが考えられる。 以上のことより、ナップ背後の空気室は、ナップが何ら かの原因により振動し始めたときに、その振動を持続 ・ 増幅させる効果があり、ナップの振動数と空気室の固有 振動数とが離れている場合には、ナップそのものの有す る振動特性がナップの振動を支配し、両者がある程度近 つくと、空気室の固有振動の影響が大きくなりナップの 振動モードが変化し、ナップー空気室連成系としてナッ プが激しく振動し始めるもの之考えられる。実験時には 騒音レベルも計測したが、騒音レベルについてみると、 振動していない時には 80 90dB, 低いモードで振動して いる時には 90 100dB 程度であったが、モードが遷移し た時には騒音レベルもかなり大きくなり、100〜110dB 程 度あった。

表ー 2 は各体積条件ごとのナップ振動の発生状況を示 したものである。この表より、空気室体積が大きくなる ほどナップ振動は起こりやすくなり、ある体積条件、本 実験の場合には体積条件 III の時には、ほとんどの場合高 い振動モードに遷移し、さらに空気室を大きくしていく と振動は発生しにくくなることがわかる。また、この表 より、空気室開放の場合を除いて、いずれの体積条件に おいても落下高の増加とともに、振動が起こる流量の上 限は大きくなり、空気室体積が増加すると振動が起こる ための流量の上限も大きくなることがわかる。
表ー2 ナップ振動の発生状況

\begin{tabular}{|c|c|c|c|c|c|c|}
\hline 体積条件 I & $\begin{array}{c}\mathrm{Q}(1 / \mathrm{s}) \\
3.1\end{array}$ & 3.9 & 4.8 & 5.7 & 6.7 & 7.8 \\
\hline $\mathrm{h}_{\mathrm{f}}=115 \mathrm{~cm}$ & $\bigcirc$ & $\triangle$ & $\triangle$ & $\times$ & - & - \\
\hline 125 & $\bigcirc$ & $\bigcirc$ & $\triangle$ & $\triangle$ & $\times$ & - \\
\hline 135 & - & $\bigcirc$ & $\bigcirc$ & $\bigcirc$ & $\times$ & $\times$ \\
\hline 145 & - & $\bigcirc$ & $\bigcirc$ & $\bigcirc$ & $\bigcirc$ & $\bigcirc$ \\
\hline 155 & - & $\bigcirc$ & $\bigcirc$ & $\bigcirc$ & $\bigcirc$ & $\bigcirc$ \\
\hline
\end{tabular}

\begin{tabular}{|c|c|c|c|c|c|c|}
\hline 体積条件 II & 3.1 & 3.9 & 4.8 & 5.7 & 6.7 & 7.8 \\
\hline $\mathrm{h}_{\mathrm{f}}=115 \mathrm{~cm}$ & $\bigcirc$ & $\bigcirc$ & $\times$ & $\times$ & - & - \\
\hline 125 & $\bigcirc$ & $\bigcirc$ & $\bigcirc$ & $\bigcirc$ & $\triangle$ & - \\
\hline 135 & - & $\bigcirc$ & $\bigcirc$ & $\bigcirc$ & $\bigcirc$ & $\bigcirc$ \\
\hline 145 & - & $\bigcirc$ & $\bigcirc$ & $\bigcirc$ & $\bigcirc$ & $\bigcirc$ \\
\hline 155 & - & $\bigcirc$ & $\bigcirc$ & $\bigcirc$ & $\bigcirc$ & $\bigcirc$ \\
\hline
\end{tabular}

\begin{tabular}{|c|c|c|c|c|c|c|}
\hline 体皘条件吕 & 3.1 & 3.9 & 4.8 & 5.7 & 6.7 & 7.8 \\
\hline $\mathrm{h}_{\mathrm{f}}=115 \mathrm{~cm}$ & $\bigcirc$ & $\bigcirc$ & $\bigcirc$ & $\times$ & - & - \\
\hline 125 & $\bigcirc$ & $\bigcirc$ & $\bigcirc$ & $\bigcirc$ & $\bigcirc$ & - \\
\hline 135 & - & $\bigcirc$ & $\bigcirc$ & $\bigcirc$ & $\bigcirc$ & $\bigcirc$ \\
\hline 145 & - & $\bigcirc$ & $\bigcirc$ & $\bigcirc$ & $\bigcirc$ & $\bigcirc$ \\
\hline 155 & - & $\bigcirc$ & $\bigcirc$ & $\bigcirc$ & $\bigcirc$ & $\bigcirc$ \\
\hline
\end{tabular}

\begin{tabular}{|c|c|c|c|c|c|c|}
\hline 体積条件IV & 3.1 & 3.9 & 4.8 & 5.7 & 6.7 & 7.8 \\
\hline $\mathrm{h}_{\mathrm{f}}=115 \mathrm{~cm}$ & $\times$ & $\times$ & $\times$ & $\times$ & - & - \\
\hline 125 & $\times$ & $\times$ & $\times$ & $\times$ & $\times$ & - \\
\hline 135 & - & $\times$ & $\times$ & $\times$ & $\times$ & $\times$ \\
\hline 145 & $\bigcirc$ & $\times$ & $\times$ & $\times$ & $\times$ & $\times$ \\
\hline 155 & - & $\bigcirc$ & $\bigcirc$ & $\bigcirc$ & $\times$ & $\times$ \\
\hline
\end{tabular}

○:ナップ振動あり, ○ : モードの遷移あり

$\triangle:$ 間欠的に振動, $\times$ : 振動せず,

$-:$ 計測無し

\section{4. 結 論}

本研究は、ナップの振動に及ぼす背後空気室の効果について背後空気室の固有振動数との関連で検討した。 その結果、従来明らかにされていなかったナップの振動のモードが遷移する現象のメカニズムが明らかにさ れた。すなわち、ナップ背後の空気室はナップ振動において重要なパラメーターであり、空気室が開放状態 であってもナップ振動が発生することから、空気室はナップ振動を持続・増幅させる役割を果たし、ナップ の振動数之空気室の固有振動数とが近い場合には、ナップ振動の卓越周波数が遷移して、ナップは空気室の 固有振動数付近で激しく振動することが明らかにされた。したがって、Petrikat ${ }^{8)}$ や Pariset ${ }^{9)}$ によると、 ナップ振動の原因は、外的要因によるナップ背後空気室内の圧力変動であると説明しているが、本研究の結 果、これはナップ振動の直接の原因ではなく、別の何らかの原因によって振動を起こしたナップが逆に空気 室の振動を誘発したものであるといえる。

\section{参考文献}

1) 名合宏之・前野詩朗・内藤明・戸梶直人 : 越流型フラップゲートのナップの振動特性に関する研究、第 41回中国四国支部研究発表会講演概要集、pp.144-145, 1989. 
2) 内藤明・前野詩朗・名合宏之 : 越流型フラップゲートの振動特性に関する研究、土木学会第44回年次学 術講演会、pp.436-437, 1989.

3) 名合宏之・前野詩朗・岡田健一・大田 勝 : フラップゲートの振動とその防止に関する研究、土木学会 第45回年次学術講演会、pp.556-557, 1990.

4) 波多野良識・石井宏幸・名合宏之・前野詩朗 : フラップゲートを越流するナップの振動に関する基䃈的 研究、第43回中国四国支部研究発表会講演概要集、pp.228-229, 1991.

5) H. I. Schwartz : Nappe Oscillation, J. Hyd. Div. Proc. ASCE, HY6, pp. 129-143, 1964.

6) 竹林征三・角 哲也・箱石憲昭 : 堰などからの放流に伴う低周波空気振動の発生機構、ダム技術、No.71, pp.4-17, 1992.

7) C. W. Knisely : Helmholtz Resonator Model of Nappe Oscillations, Proceedings of 6th Congress of Asian and Pacific Regional Division, IAHR, Kyoto, Japan, pp.667-674, 1988.

8) K. Petrikat : Beitrag zur Untersuchung der Schwingungsanfachung an ueberstoemten Wehren, Deutsche Wasserwirtschaft, Jahrgang 36, 1941.

9) E. Pariset : Etude sur la Vibration des Lames Déversants, Proceeding of the 6th General Meeting of the international Association for Hydraulic Research, The Hague, Aug. 31-Sep.6, 1955 